\title{
Turisztikai célú támogatások szerepe az Észak-Alföld Régió fejlődésében
}

\section{Role of grants for tourism purposes in development of the Northern Great Plain region}

\author{
É. DARABOS ${ }^{1}$, T. O. NAGY ${ }^{2}$ \\ ${ }^{1}$ Debreceni Egyetem, Gazdálkodástudományi Kar, Számviteli és Pénzügyi Intézet \\ darabos.eva@econ.unideb.hu, \\ ${ }^{2}$ Debreceni Egyetem, Gazdálkodástudományi Kar, Számviteli és Pénzügyi Intézet \\ nagy.tunde@econ.unideb.hu
}

\begin{abstract}
Absztrakt. A tanulmány célja, fóbb makro gazdasági mutatók alapján az Észak-alföldi régió fejlődésének, valamint a kapott uniós - ezen belül a turisztikai célú - támogatások összegének bemutatatása, illetve a támogatások hatásainak vizsgálata. Az adatok alapján megállapítható, hogy a régió jelentôs támogatásban részesült a 20072013. évek során, a gazdasági fejlettség tekintetében az utolsó helyen szerepel, de több területen kedvezőbb teljesítményt ért el. A szálláshely-vendéglátás nemzetgazdasági ágat nehéz önállóan vizsgálni, egyrészt számos más terület együttes hatásaként fejlődik, másrészt a turisztikai jellegü fejlesztések más ágazatok számára is felhasználhatókká válnak, új vállalkozások, beruházások indulnak, ugyanakkor nem csak a vállalatok, hanem az önkormányzatok turizmusból származó bevétele is nő. A statisztikai adatok alapján rámutatunk arra, hogy a régióban a turizmus-vendéglátás területén a fejlesztések eredménye csak mérsékelt és megyénként eltérő mértékü.
\end{abstract}

Abstract. Aim of the treatise is, based on main macroeconomic indicators, to present the development of the Northern Great Plain region and the amount of EU grants received, including the ones for tourism purposes, as well as to examine the effects of grants. Based on the data, it can be concluded the region received significant grants during the years 2007-2013; it is in last place in view of the economic development but has achieved better performance in several areas. It is difficult to examine the accommodation and food service national economic sector independently: in one respect, it develops by the combined impact of several other areas, on the other hand, the tourism-related developments become usable for other sectors as well, new enterprises and investments are launched, at the same time, not only the companies' but the municipalities' revenues from tourism are increasing. Based on the statistical data, attention will be drawn to the fact that the outcome of developments is just moderate in the area of catering and tourism in the region and has a different rate by county.

\section{Bevezetés}

A turizmus a nemzetgazdaság több ágazatát és a társadalom számos rétegét érintő tevékenység, ún. fogyasztási szegmens és egyre inkább, mint a nemzetgazdaság egyik húzóágazatként tekinthetjük. A teljesítménye „interszektorális jellegéből adódóan” több szakágazat - pl. kultúra, közlekedés, 
vendéglátás, szálláshely stb. - teljesítményében mutatható ki [5]. A kutatás során elsősorban a szálláshely-vendéglátás szolgáltatás nemzetgazdasági ágat elemezzük a KSH adatai alapján.

Az Észak-Alföld turisztikai régióban a hagyományos turisztikai termékeken túl rendelkezésre állnak azok a gyógy- és termálvizek, melyek a régió egészség-turizmusában vezető szerepet játszanak [4], [10], [11]. Az egészség turizmus mellett a kulturális, a falusi, a gasztronómiai, a fesztivál [2],[3],a konferencia és nem utolsó sorban a sport turizmus feltételei is adottak, s mindezek tőke- és infrastruktúra igénye komplex kínálatot követel az adott településektől. Könyves és szerzőtársa tanulmányukban az Észak-alföldi régi turisztikai célú fejlesztéséről, stratégiájáról, projektekről és a turisztikai termékek kínálatáról a 2007-2013. évekre vonatkozóan átfogó képet adnak [5].

Először a régió főbb nemzetgazdasági adatait, a turizmus szerepének kiemelése mellett mutatjuk be, majd a Regionális Operatív Programok célrendszerét, az Észak-alföldi régió turisztikai stratégia programjait [13], [14]. Ezt követően a célkitűzésnek megfelelően a kapott támogatások felhasználását elemezzük, A projektek eredményének kimutatása nem egyszerű feladat, mert a programok célkitűzései, a prioritásai között vannak átfedések, pl. a gazdaság- vagy a közlekedés fejlesztést célzó projektek közvetlenül vagy közvetve segítik a turizmus fejlődését is.

Az Észak-alföldi régióban az adottságok elsősorban a megyeszékhelyekre koncentrálódnak (azon belül is kiemelkedő Debrecen jelentősége). Debrecen, Nyíregyháza, Szolnok elsősorban szállásférőhelyi és vendéglátói kapacitásai miatt országos és nemzetközi sport, szórakoztató rendezvényeknek, konferenciák rendezésének, de a kisebb létszámú, szakosított rendezvények számára is helyet adnak [6], [7]. A régió konferenciaturizmusának jövőbeli alakulását alapjaiban meghatározza a debreceni konferenciaközpont, de mindhárom városban - különösképp Debrecenben - nagy múltú egyetemi, tudományos élet is folyik, a rendelkezésre álló infrastruktúra pedig helyet biztosít. A régióban felhasznált források és a projektek által elért eredmények elemzése során megyei szintű sajátosságokat is kiemelünk.

\section{1. Észak Alföld főbb gazdasági mutatói}

$\mathrm{Az}$ Észak-alföldi gazdasági régiót Jász-Nagykun-Szolnok, Hajdú-Bihar és Szabolcs-Szatmár-Bereg megye alkotja. A régiónak kulcsfontosságú szerepe van közlekedés-földrajzi szempontból, csomópont közúti és a vasúti közlekedés szempontjából a főváros és a megyeszékhelyek között, az ország keleti és nyugati tengelyén helyezkedik el, Európa keleti és nyugati részét kapcsolja össze. Az M3-as autópálya, a nemzetközi (debreceni) és a regionális (szolnoki, nyíregyházi, kunmadarasi) repülőterek a régió gazdasági fejlődésében fontos szerepet játszanak.

Az Észak-alföldi régió az egy főre jutó GDP tekintetében a KSH adatai szerint 2009-2014-es években a régiók között a hatodik volt (1. táblázat), 2015-2016-ban Dél-Dunántúl után a 7. helyre esett vissza. 2009-ban az egy főre jutó GDP 1,7 millió forint, 2016-ban közel 2,3 millió forint volt, ami 2009-ben az országos átlag 64,8 \%-át, 2016-ban 63,7 \%-át jelenti. A vizsgált időszakban régión belül a megyék teljesítménye között is jelentős különbségek vannak, amíg Hajdú-Biharban 2009-ben az egy főre jutó GDP az országos átlag 74,3 \%-a volt, a következő évek növekedése után 2016-ra 70 \%-ra csökkent, 
addig Jász-Nagykun-Szolnok megyében 54,4 \%-ról 56,6 \%-ra, Szabolcs-Szatmár-Bereg megyében 54,4 \%-ról 56,6 \%-ra emelkedett.

\begin{tabular}{|c|c|c|c|c|c|c|c|c|c|}
\hline \multicolumn{10}{|c|}{ Egy főre jutó bruttó hazai termék, ezer Ft } \\
\hline Területi egység & 2008 & 2009 & 2010 & 2011 & 2012 & 2013 & 2014 & 2015 & 2016 \\
\hline Közép-Magyarország & 13077 & 13015 & 13364 & 13676 & 13905 & 14570 & 15320 & 16034 & 16408 \\
\hline Közép-Dunántúl & 2696 & 2421 & 2586 & 2746 & 2754 & 2931 & 3189 & 3445 & 3622 \\
\hline Nyugat-Dunántúl & 2618 & 2458 & 2685 & 2858 & 2876 & 3036 & 3480 & 3698 & 3887 \\
\hline Dél-Dunántúl & 1760 & 1721 & 1737 & 1796 & 1826 & 1908 & 2016 & 2044 & 2133 \\
\hline Észak-Magyarország & 2070 & 1950 & 1967 & 2032 & 2064 & 2206 & 2437 & 2677 & 2750 \\
\hline Hajdú-Bihar & 1044 & 1053 & 1093 & 1157 & 1182 & 1186 & 1304 & 1341 & 1348 \\
\hline Jász-Nagykun-Szolnok & 694 & 700 & 648 & 712 & 721 & 771 & 816 & 839 & 883 \\
\hline Szabolcs-Szatmár-Bereg & 821 & 804 & 826 & 850 & 899 & 920 & 1040 & 1088 & 1149 \\
\hline Észak-Alföld & 2559 & 2557 & 2567 & 2719 & 2802 & 2876 & 3159 & 3269 & 3380 \\
\hline Dél-Alföld & 2414 & 2302 & 2319 & 2479 & 2554 & 2720 & 2991 & 3158 & 3239 \\
\hline Ország összesen & 27194 & 26425 & 27225 & 28305 & 28781 & 30247 & 34591 & 34324 & 35420 \\
\hline \multicolumn{10}{|c|}{ Egy főre jutó bruttó hazai termék az országos átlag százalékában } \\
\hline Közép-Magyarország & 165,8 & 168,0 & 165,8 & 161,8 & 162,6 & 161,0 & 155,9 & 153,8 & 151,7 \\
\hline Közép-Dunántúl & 90,1 & 83,4 & 86,6 & 88,6 & 88,1 & 89,4 & 90,5 & 93,0 & 94,8 \\
\hline Nyugat-Dunántúl & 96,8 & 93,5 & 99,1 & 101,3 & 100,7 & 100,8 & 107,0 & 107,8 & 109,5 \\
\hline Dél-Dunántúl & 67,9 & 68,7 & 67,6 & 67,5 & 67,9 & 67,7 & 66,8 & 64,8 & 65,8 \\
\hline Észak-Magyarország & 62,1 & 60,8 & 60,1 & 60,2 & 59,5 & 61,0 & 63,0 & 66,2 & 66,3 \\
\hline Hajdú-Bihar & 70,9 & 73,7 & 74,3 & 75,7 & 75,1 & 71,8 & 73,3 & 71,8 & 70,0 \\
\hline Jász-Nagykun-Szolnok & 64,6 & 67,6 & 61,2 & 65,2 & 64,0 & 65,5 & 64,7 & 63,6 & 65,2 \\
\hline Szabolcs-Szatmár-Bereg & 53,3 & 54,2 & 54,4 & 54,1 & 54,9 & 53,5 & 56,0 & 55,5 & 56,6 \\
\hline Észak-Alföld & 62,6 & 64,8 & 63,4 & 64,8 & 64,6 & 63,2 & 64,5 & 63,5 & 63,7 \\
\hline Dél-Alföld & 67,0 & 66,1 & 64,8 & 67,0 & 68,1 & 69,3 & 71,0 & 71,5 & 71,4 \\
\hline Ország összesen & 100,0 & 100,0 & 100,0 & 100,0 & 100,0 & 100,0 & 100,0 & 100,0 & 100,0 \\
\hline
\end{tabular}

1. táblázat: Egy före jutó bruttó hazai termék összege és az országos átlag százalékában Forrás: [19]. 6.3.1.2. Egy före jutó bruttó hazai termék (2000-)

A szálláshely-szolgáltatás, vendéglátás bruttó hozzáadott értékkel mért teljesítménye folyó áron számítva 2007-2011-es években 440 milliárd forint körül alakult, az ezt követő években folyamatos növekedés figyelhető meg, 2016-ra a szektor teljesítménye elérte 515 milliárd forintot. A szálláshelyszolgáltatás, vendéglátás bruttó hozzáadott értékhez való hozzájárulása a 2007. évi 2 \%-ról 2016-ra 1,7 \%-ra csökkent [19].

2016-ban a szektorban a vállalkozások 193 ezer főt foglalkoztatottak, előző évhez képest 10 fővel többet, ez 5,2 \%-os növekedésnek felel meg.

Változatlanul alacsony a szálláshely-szolgáltatás, vendéglátás területén a dolgozók átlagkeresete. Az alkalmazásban állók havi bruttó átlagkeresete 2016-ban a teljes nemzetgazdasági átlagot tekintve 263 ezer forint volt, egy év alatt 6,1 \%-kal nőtt, miközben a szektorban mindössze 166 ezer forintot tett ki, ami 5,3 \%-os növekedést jelent.

\section{Regionális Operatív Programok célrendszere}

A regionális opratív programok célja a regionális társadalmi, gazdasági jólét előmozdítása. Az adott régiót jellemző életminőség javítása, a foglalkoztatási szint emelése, új munkahelyek teremtése, a 
régión belü hátrányos helyzetű térségek felzárkóztatása. A régiók közötti forráselosztás az adott régió fejlettségétől és a lakosság számától függött.

Az Országos Fejlesztési Koncepció (OFK) 9db átfogó fejlesztési célhoz Reginális Operatív Programot (ROP) rendelt. Az OFK által megfogalmazott " a magyar gazdaság versenyképességének tartós növekedése" stratégiai célhoz a ROP célkitűzéseiből "az infrastruktúra fejlesztései, klaszterfejlődés támogatása, turisztikai fejlesztések, regionlis gazdaságfejlesztések“ speciális programok kapcsolódnak [14].

Az Észak-alföldi operatív program átfogó célként fogalmazza meg a régió természeti és társadalmi értékeinek megőrzését, a regionális versenyképesség erősítését, valamint a régión belüli területi különbségek csökkentését. Enek megfelelően 5 specifikus cél, valamint a célok megvalósítása során érvénysítendő prioritások kerültek megfogalmzásra (1.ábra)

\section{Az Észak-alföldi operatív program célrendszere}

Átfogó cél

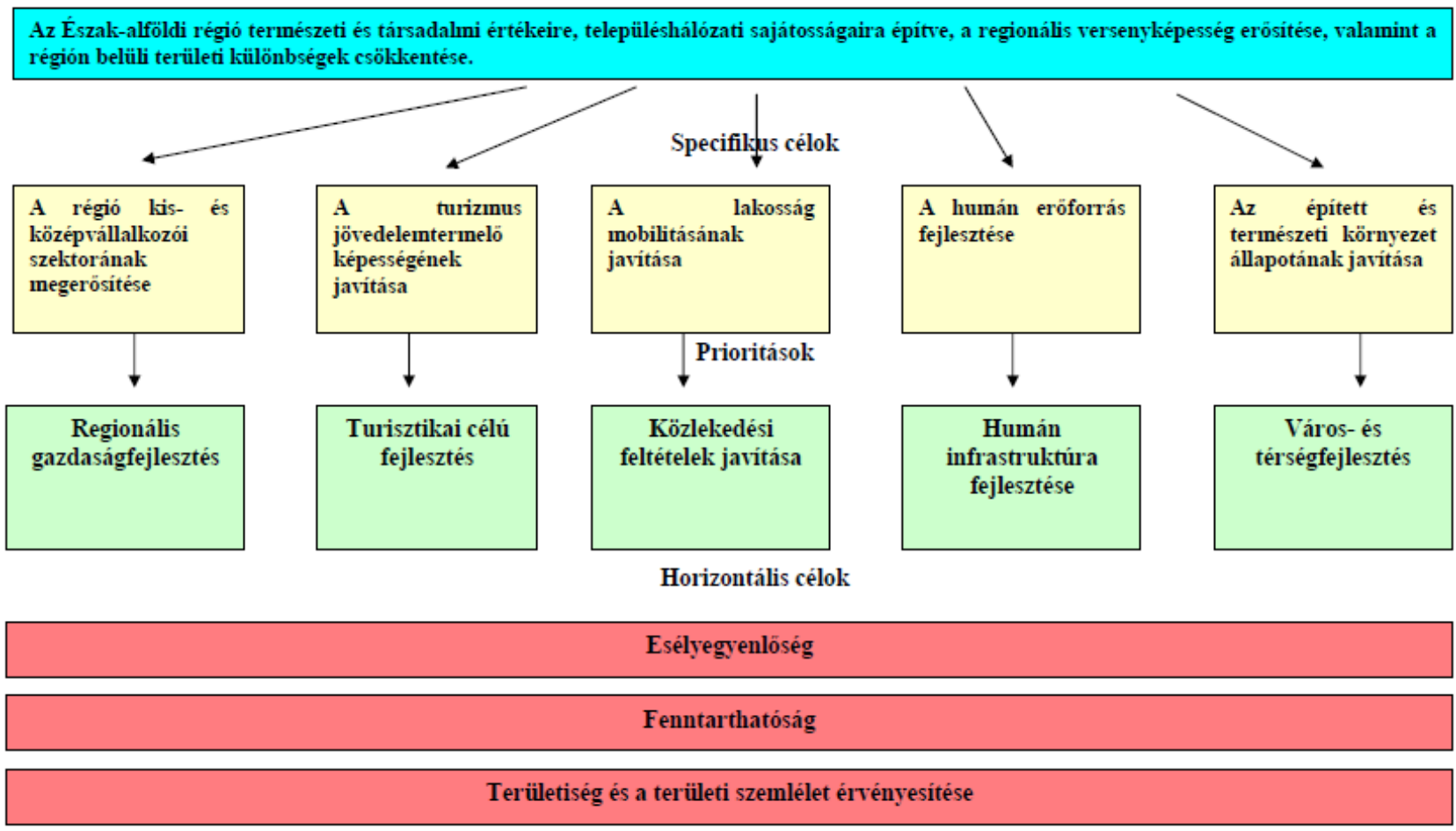

1. ábra: Az Észak-Alföld Operatív Program célrendszere Forrás: [14]

A fenntarthatóság kiemelt szerepet kell, hogy betöltsön a későbbiekben is a turizmusban. Lakner és szerzőtársai [8] kiemelik a közigazgatási struktúra korszerűsítésének és átszervezésének fontosságát, a források optimális kihasználására összpontosítva. Emellett a fenntartható idegenforgalom irányításával kapcsolatos döntések megerősítését azért, hogy a különböző érdekcsoportok bevonásával a helyi döntéshozatalban történő tudatos tervezés fejlesztése minimalizálhassa a turizmus környezeti terheit. 
A regionális operatív programok forrásainak eredményes forrásfelhasználásához -az uniós előírások szerint -kapcsolt indikátor-mutatók köre a régiókban megegyezett. Ezek: a támogatott magán beruházások összege, a 20-64 év közötti lakosság foglalkoztatási szintjének változása, a teremtett új munka-helyek száma, ebből a nők és a hátrányos helyzetű területeken élők aránya (ún. output indikátorok), a régiós egy főre jutó GDP színvonal változása, a foglalkoztatottsági ráta változása (hatásindikátor). A regionális programszintű felhasználás eredményeit jelző egységes hatás és magindikátor mutatók halmaza adott volt, az egyes regionális programokhoz a régiók maguk határozták meg a prioritásszintű output-, eredmény-és hatásindikátorokat és célértékeiket. [14]

\section{3. Észak-Alföldi Régió Turizmusfejlesztési Stratégiája, 2007-2013}

Az Észak-alföldi régió 2007-2013. évekre vonatkozó Turizmusfejlesztési Stratégiája szerint a turizmus a régióban meghatározó húzóágazattá válik, amely a turisztikai kis- és középvállalkozások számára vonzó perspektívát jelent, multiplikátor hatásain keresztül pedig a helyi gazdasági szereplők számára keresletet generál. Javul a turisztikai vállalkozások rentabilitása és versenyképessége, a minőségorientált, hosszú-távú profit-érdekeltség szemléletmód lesz a meghatározó. Új vállalkozások, beruházások indulnak, a turisztikai jellegű fejlesztések más ágazatok számára is felhasználhatókká válnak, a desztinációk (önkormányzatok) turizmusból származó bevétele nő. A régió felzárkózásának egyik leghatékonyabb eszköze lesz a turizmus. A turizmus érdekében történt fejlesztések javítják a lakosság életkörülményeit is. A belföldi turizmus bővülésével a lakosság életminősége jelentősen javul, az önbecsülés, a régió-identitás erősödik, a turizmus régión belüli gazdasági-társadalmi elismertsége nő [16].

A fenti célok, illetve hatások elérése érdekében az Észak-alföldi régió turizmusfejlesztési célpiramis programokat fogalmaz meg, melyek a következők:

- vonzerő- és attrakciófejlesztés,

- fogadási feltételek javítása, szolgáltatásfejlesztés,

- régiós turisztikai marketing,

- $\quad$ szervezeti és működési feltételek javítása.

Ezekre a programokra, illetve a kapcsolódó alprogramokra uniós fejlesztési forrásokat lehetett pályázni. Az új turisztikai termékek létrehozását célzó alprogramok, intézkedések elsősorban a magánszektor fejlesztését célozták, a fejlesztések többsége a magánszektorban került megvalósításra.

A társadalmi-gazdasági környezet és a turizmus egymással folyamatos kölcsönhatásban van egy-egy térségen belül. A meglévő földrajzi, természeti adottságok leginkább a - korábbi befektetések, vállalkozási környezet, emberi döntések eredményeként - rájuk épülő infrastruktúra, a kialakított attrakciók, a működő programok, közlekedési lehetőségek által vonzzák oda és tartják ott rövidebbhosszabb ideig a látogatókat [1]. A turisztikai potenciál, jelenlét ugyanakkor visszahat a térség életére, segítheti a népesség helyben maradását, a munkanélküliség csökkenését, a további infrastrukturális fejlődést, a befektetéseket, a vállalkozásalapítási készséget, a jövedelemhez jutást éppúgy, mint a gazdaságnak bármely más, jól funkcionáló területe. Magyarország területileg legnagyobb kiterjedésű idegenforgalmi régiói az Alföldön találhatók: a hazánk területének csaknem egyötödét, több mint 18 
ezer km-t elfoglaló dél-alföldi, valamint a több mint 15 ezer km-en fekvő észak-alföldi. A legkisebb méretű turisztikai régiók az ország két legjelentősebb tava körül a környező megyékből kialakított balatoni, illetve a Tisza-tavi régió, területük nem éri el a 4 ezer km-t.

\section{Regionális Operatív Programok keretében a forrás igények és felhasználások elemzése}

A Regionális Operatív Programok közül az Észak-Alföldi Operatív Program rendelkezésre álló keretösszege volt a legmagasabb. Hajdú-Bihar és Szabolcs-Szatmár-Bereg megye forrásigénye a magasak között van, Jász-Nagykun-Szolnok megye forrásigénye (198,6 Mrd Ft) is átlagon felüli.

A 2. táblázat adatai alapján látható a régió által igényelt támogatás és a leszerződött összeg megyénkénti bontásban.

\begin{tabular}{|l|c|c|c|c|}
\hline \multicolumn{1}{|c|}{ Megye } & $\begin{array}{c}\text { Igényelt } \\
\text { támogatás } \\
\text { (Mrd Ft) }\end{array}$ & $\begin{array}{c}\text { Leszerződött } \\
\text { összeg } \\
\text { (Mrd Ft) }\end{array}$ & $\begin{array}{c}\text { Igényelt } \\
\text { támogatás } \\
\text { (fó/ezer Ft) }\end{array}$ & $\begin{array}{c}\text { Leszerződött } \\
\text { összeg } \\
\text { fó/ezer Ft }\end{array}$ \\
\hline Hajdú-Bihar & 289,9 & 120,9 & 537,3 & 224,1 \\
\hline Jász-Nagykun-Szolnok & 198,6 & 72,8 & 517,9 & 190,0 \\
\hline Szabolcs-Szatmár-Bereg & 280,6 & 116,9 & 499,5 & 207,8 \\
\hline Észak-Alföld & $\mathbf{7 6 8 , 9}$ & $\mathbf{3 1 0 , 6}$ & - & - \\
\hline
\end{tabular}

2. táblázat: A ROP keretében igényelt támogatások és leszerződött összegek - Észak-Alföld megyei bontásban Forrás: [17], [18]

A Századvég Gazdaságkutató Zrt. adatai [18] szerint az észak-alföldi térség esetében a regionális gazdaságfejlesztés és a közlekedésfejlesztés prioritás forrásai iránti igény relatíve alacsony volt, az adott prioritások az összes igényhez viszonyítva külön-külön kb. 13-13 \%-ot képviseltek. Az alacsony igény ellenére a közlekedésfejlesztési célra elnyert összegek az összes támogatás ötödét tették ki. Regionális szinten a turizmusfejlesztés, valamint a város- és térségfejlesztés iránti kereslet megközelítőleg azonos szinten áll (22-23\%), míg a humáninfrastruktúra fejlesztés közel 27 \%-os részaránnyal szerepelt. Az egyes prioritások iránti keresletek - a turizmus- és a humáninfrastruktúra fejlesztés kivételével - viszonylag egységes képet mutattak. A turizmusfejlesztés kapcsán Hajdú-Bihar megye 27,4 \%-os (ezen belül is Hajdúszoboszlói és Balmazújvárosi járás 40, illetve 45 \%-os részaránya), míg a humáninfrastruktúra fejlesztések iránti igény Szabolcs-Szatmár-Bereg megyében bizonyult a legmagasabbnak (32,4 \% a megye összes ROP-os forrásigényén belül). A magas kereslet ellenére az elnyert források részaránya Szabolcsban mérsékelt $(23,1 \%)$ volt. A járások élmezőnyét a Jász-Nagykun-Szolnok megyei Törökszentmiklós járás vezette, ahol 29 nyertes pályázatból 15 esetében valamilyen humán-infrastruktúra fejlesztést valósítottak meg, az igénylések közel negyede ehhez a prioritáshoz kapcsolódott, a leszerződött összegek aránya csak 14,2 \%. A régióban HajdúBihar tudta elképzeléseit legnagyobb mértékben megvalósítani.

A 3. táblázat adatai igazolják, hogy az Észak-alföldi régió a legtöbb területen a projektek számát, a forrásokat és az egy projektre eső összeget tekintve 1-2. helyen szerepel. A finanszírozott területek közül a turizmusra fordított összeg 286 milliárd Ft, ami a gazdaságfejlesztést célzó program után a második legmagasabb, az egy projektre eső összeg (275,3 millió Ft) tekintetében is a második a 
közlekedés után (299,4 millió Ft). A turizmus projektjei három nagyobb kategóriába sorolhatók, ezen belül is jelentősebb az attrakciófejlesztés, melyet a szálláshely finanszírozása követ.

\begin{tabular}{|c|c|c|c|c|c|c|c|c|c|}
\hline \multirow[b]{2}{*}{ Tématerület } & \multicolumn{2}{|c|}{ Összesen } & \multirow{2}{*}{$\begin{array}{c}\text { millió } \\
\text { Ft/ } \\
\text { program }\end{array}$} & \multicolumn{6}{|c|}{ Projektek száma (db) } \\
\hline & db & $\begin{array}{c}\text { Mrd } \\
\text { Ft }\end{array}$ & & DAOP & DDOP & ÉAOP & ÉMOP & KDOP & NYDOP \\
\hline Gazdaságfejlesztés & 2532 & 191,8 & 75,8 & 808 & 375 & 509 & 416 & 323 & 320 \\
\hline Turizmus & 1039 & 286 & 275,3 & 175 & 176 & 190 & 185 & 167 & 146 \\
\hline Attrakció & 741 & 237,8 & 320,9 & 128 & 104 & 148 & 124 & 126 & 111 \\
\hline Szálláshely & 186 & 42,8 & 230,1 & 41 & 39 & 34 & 41 & 17 & 14 \\
\hline $\begin{array}{l}\text { TDM/turisztikai } \\
\text { klaszter }\end{array}$ & 112 & 5,4 & 48,2 & 6 & 33 & 8 & 20 & 24 & 21 \\
\hline $\begin{array}{l}\text { Humán } \\
\text { közSzolgáltatás }\end{array}$ & 1709 & 1709 & 146,7 & 281 & 228 & 406 & 451 & 144 & 220 \\
\hline Közlekedés & 805 & 241 & 299,4 & 244 & 102 & 208 & 77 & 104 & 80 \\
\hline Környezet & 678 & 139,8 & 206,2 & 63 & 140 & 142 & 239 & 76 & 87 \\
\hline Településfejlesztés & 841 & 202,3 & 240,5 & 114 & 52 & 119 & 443 & 50 & 62 \\
\hline Akadálymentesítés & 763 & 10,4 & 13,6 & 104 & 76 & 190 & 289 & 61 & 43 \\
\hline Civil szektor & 99 & 3,9 & 39,4 & 0 & 10 & 74 & 15 & 0 & 0 \\
\hline
\end{tabular}

3. táblázat: ROP-ok tématerületek és régiók szerinti csoportosításban

Forrás: [17], [18]

\section{A turizmus támogatásának regionális eredményei}

Nagyon nehéz számszerúsíteni, de még megbecsülni is, hogy az egyes programokba fektetett források milyen mértekben jelennek meg az adott régió fejlődésében, hogy hatnak a régiók közötti versenyben. Egyrészt a gazdaság-, a humán közszolgáltatás-, a közlekedés-, a település fejlesztés, de a környezeti feltételek jobbítása is hatással vannak a turizmusra. Másrészt a turizmus területén megjelenő vállalkozások, szolgáltatások a gazdaság más ágazatai, a helyi gazdasági szereplők számára keresletet generálnak.

A támogatások regionális gazdaság-élénkítésben játszott szerepének vizsgálatakor abból indulunk ki, hogy melyek azok a területek, ahol a fejlődés számszerüsíthető. A fejlődés egyik legfontosabb tényezője az adott területben fektetett tőke nagysága, jelen esetben a szálláshely-vendéglátás ágazatba irányuló beruházások összegének alakulása [9], hiszen a befektetők a meglévő turisztikai környezet alapján döntenek arról, hogy érdemes-e az adott területre, az adott településen beruházni. Ugyanakkor nehézségekbe is ütközik a fejlesztés hatásának kimutatása, egyrészt mert a beruházások esetenként több éven keresztül elhúzódnak, másrészt pedig pl. egy útépítés, nem csak a turizmust szolgálja, hanem a helyi közlekedést is. Egy vendéglátó ipari egység a helyi lakosság igényein túl az oda érkező turisták igényeit is szolgálja.

A szektort leginkább jellemző mutató a kereskedelmi szálláshelyeken a férőhelyek számának alakulása, hiszen a férőhelyek számának növekedése alapvetően fejlesztés, beruházás eredménye, a kapacitás bővülését jelenti. A 4. táblázat tartalmazza a kereskedelmi szálláshelyek férőhelyeinek számát, változását régiónként, illetve megyénként. Az Észak-Alföldön a férőhelyek száma a 20082009-es pénzügyi válság hatására valamelyest csökkent, a következő években azonban jelentős ingadozás figyelhető meg, a vizsgált időszakban a férőhelyek száma közel 39,8 ezerről 2013-ra 38,4 ezerre csökkent. A ROP keretében a régióban 190 turisztikai célú projektből 34 projekt szálláshely 
fejlesztést finanszírozott, átlagosan egy projektre eső összeg 230,1 millió forint (3. táblázat). Azonban a pályázati ciklus alatt nem mutatható ki egyértelmű férőhely növekedés. Az ingadozásban egyrészt szerepet játszik az, hogy bár megvalósultak új fejlesztések, de egyidejúleg számos vállalkozás megszüntette tevékenységét, vagy bezártak szállodák, pl. Debrecenben a híres Aranybika Szálló. Másrészt a 2007-tôl a ciklus alatt elfogadott pályázati forrásból a fejlesztések egy része csak a ciklus után zárult le, a hatásuk is a megvalósulást követő években jelentkezik.

\begin{tabular}{|l|c|c|c|c|c|c|c|c|c|c|}
\hline Területi egység & $\mathbf{2 0 0 8}$ & $\mathbf{2 0 0 9}$ & $\mathbf{2 0 1 0}$ & $\mathbf{2 0 1 1}$ & $\mathbf{2 0 1 2}$ & $\mathbf{2 0 1 3}$ & $\mathbf{2 0 1 4}$ & $\mathbf{2 0 1 5}$ & $\mathbf{2 0 1 6}$ & $\mathbf{2 0 1 7}$ \\
\hline $\begin{array}{l}\text { Közép- } \\
\text { Magyarország }\end{array}$ & 48028 & 52042 & 54537 & 63963 & 66496 & 61971 & 62962 & 64020 & 67730 & 66819 \\
\hline Közép-Dunántúl & 50329 & 50370 & 50350 & 56134 & 54999 & 49209 & 47512 & 45823 & 50285 & 53966 \\
\hline Nyugat-Dunántúl & 47289 & 47674 & 51060 & 58582 & 51403 & 53140 & 52711 & 56076 & 55693 & 54196 \\
\hline Dél-Dunántúl & 53527 & 50398 & 56141 & 52593 & 53619 & 92170 & 95535 & 94963 & 94847 & 65573 \\
\hline $\begin{array}{l}\text { Észak- } \\
\text { Magyarország }\end{array}$ & 37071 & 34685 & 34754 & 37679 & 41849 & 40918 & 39127 & 38951 & 38861 & 39883 \\
\hline Észak-Alföld & 39799 & 39712 & 39382 & 41909 & 37701 & 38355 & 42105 & 41218 & 40656 & 39496 \\
\hline Hajdú-Bihar & 16580 & 15750 & 16470 & 15470 & 14333 & 15982 & 18170 & 17211 & 17452 & 16942 \\
\hline $\begin{array}{l}\text { Jász-Nagykun- } \\
\text { Szolnok }\end{array}$ & 12536 & 13523 & 13128 & 14954 & 12451 & 11887 & 13451 & 12892 & 12452 & 11703 \\
\hline $\begin{array}{l}\text { Szabolcs-Szatmár- } \\
\text { Bereg }\end{array}$ & 10683 & 10439 & 9784 & 11485 & 10917 & 10486 & 10484 & 11115 & 10752 & 10851 \\
\hline Dél-Alföld & 26846 & 26992 & 39382 & 41909 & 30330 & 29878 & 30515 & 32528 & 32982 & 31752 \\
\hline Ország összesen & 302889 & 301873 & 311490 & 340402 & 336397 & 365641 & 370467 & 373579 & 381054 & 351685 \\
\hline
\end{tabular}

4. táblázat: Kereskedelmi szálláshelyek férőhelyei régiónként és megyénként (db)

Forrás: [19]. 6.4.5.1. A kereskedelmi szálláshelyek férőhelyei, július 31. (2000-)

Megjegyzés: A táblázat a 2007-es adatokat nem tartalmazza, meg kell azonban jegyezni, hogy minden régióban, így országosan is csökkent a férőhelyek száma 2007-ről 2008-ra.

A 4. táblázat adatai alapján megállapítható, hogy országosan 2008-ról 2013-ra 62,7 ezerrel csökkent a férőhelyek száma, majd 2016-ra 381 ezerre növekedett, de 2017-ben országosan 8,3 \%-os csökkenés tapasztalható, miközben a ROP keretében186 projekt 42,8 milliárd forintba került (2. táblázat).

Régiónként is jelentős eltérések mutathatók ki, míg Közép-Magyarországon és a dunántúli régiókban folyamatos növekedés figyelhető meg 2016-ig, addig a többi régióban stagnáló, enyhén ingadozó tendencia figyelhető meg, 2017-re több régióban csökkent (Dél-Dunántúl) vagy alig változott a férőhelyek száma, országosan 29,3 ezerrel csökkent a szálláshelyek férőhelyei. 


\begin{tabular}{|l|r|r|r|r|r|r|r|r|r|r|}
\hline \multicolumn{1}{|c|}{ Területi egység } & 2008 & 2009 & 2010 & 2011 & 2012 & 2013 & 2014 & 2015 & 2016 & 2017 \\
\hline Közép-Magyarország & 2895 & 2676 & 2908 & 3203 & 3497 & 3731 & 4017 & 4327 & 4635 & 4894 \\
\hline Közép-Dunántúl & 774 & 739 & 761 & 806 & 820 & 841 & 913 & 951 & 1051 & 1193 \\
\hline Nyugat-Dunántúl & 1324 & 1287 & 1379 & 1458 & 1420 & 1435 & 1483 & 1622 & 1726 & 1845 \\
\hline Dél-Dunántúl & 803 & 739 & 750 & 749 & 804 & 885 & 959 & 1011 & 1081 & 1073 \\
\hline Észak-Magyarország & 684 & 635 & 627 & 686 & 735 & 822 & 928 & 1011 & 1065 & 1159 \\
\hline Hajdú-Bihar & 395 & 359 & 349 & 336 & 323 & 353 & 399 & 445 & 469 & 505 \\
\hline Jász-Nagykun-Szolnok & 164 & 154 & 145 & 161 & 170 & 161 & 184 & 186 & 196 & 218 \\
\hline $\begin{array}{l}\text { Szabolcs-Szatmár- } \\
\text { Bereg }\end{array}$ & 131 & 118 & 124 & 134 & 128 & 141 & 147 & 160 & 164 & 179 \\
\hline Észak-Alföld & 690 & 631 & 618 & 632 & 620 & 654 & 730 & 792 & 828 & 902 \\
\hline Dél-Alföld & 482 & 443 & 430 & 486 & 489 & 517 & 610 & 690 & 730 & 818 \\
\hline Ország összesen & 7651 & 7151 & 7473 & 8021 & 8385 & 8885 & 9640 & 10403 & 11117 & 11884 \\
\hline
\end{tabular}

5. táblázat. Kereskedelmi szálláshelyek forgalma régiónként és megyénként (ezer fó)

Forrás: [19]. 6.4.5.2. A kereskedelmi szálláshelyek vendégforgalma (2000-)

Az 5. táblázat és a 2. ábra adatai alapján látható, hogy 2008-2009-es években a kereskedelmi szálláshelyeken mind vendégek száma, mind az eltöltött vendégéjszaka száma csökkent, 2010-ben következett be jelentős növekedés. A következő években a külföldi vendégek által eltöltött vendégéjszakák száma gyorsabban nőtt, mint a belföldi. 2007 és 2017 között a kereskedelmi szálláshelyek vendégforgalma 7,6 millióról 11,9 millió főre növekedett, ami közel 55 \%-os növekedésnek felel meg, a vendégéjszakák száma 20,1 millióról 29,8 millióra emelkedett, ami 47,9%os növekedést jelent.

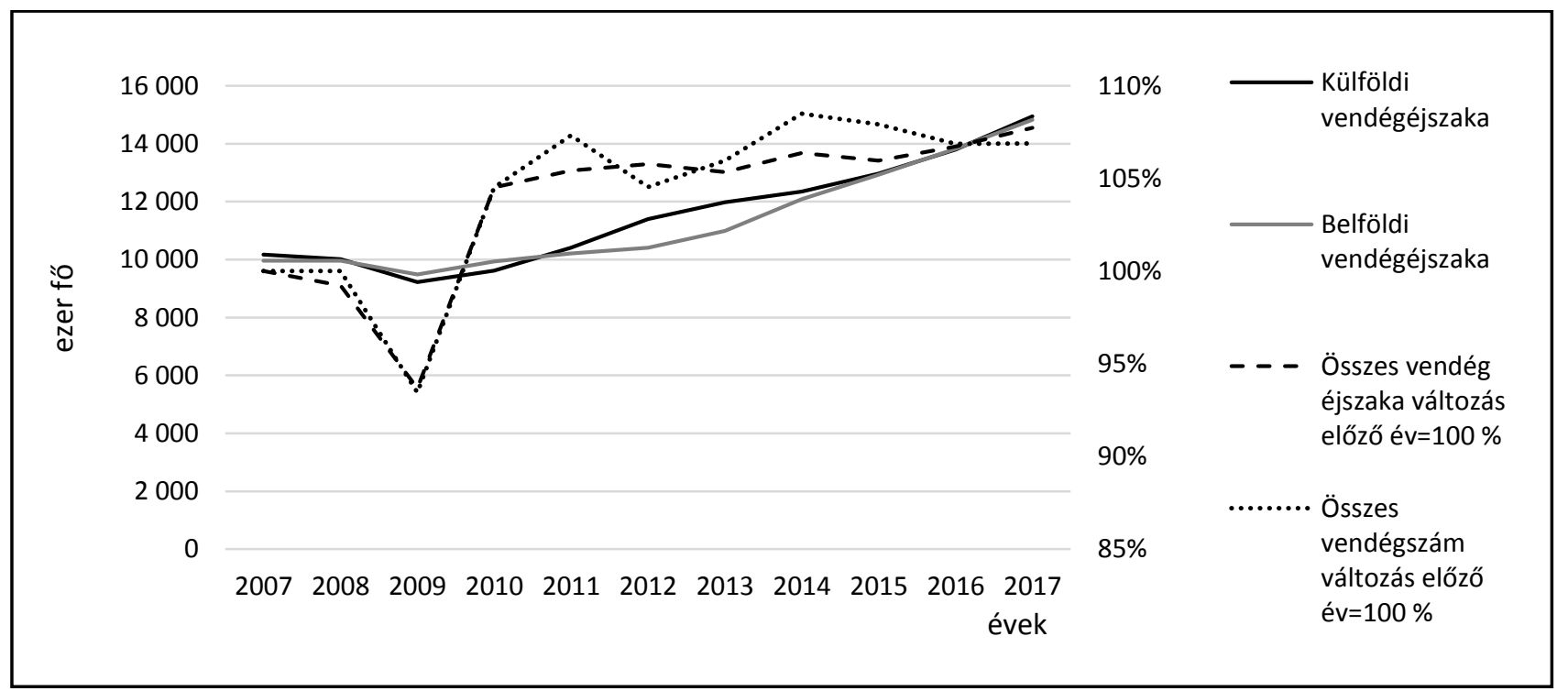

2. ábra. Kereskedelmi szálláshelyeken eltöltött vendégéjszakák száma, változása országosan és a vendégek számának változása (2007-2017)

Forrás: [19], 6.4.5.2. A kereskedelmi szálláshelyek vendégforgalma (2000-); 4.5.14. A kereskedelmi szálláshelyeken eltöltött vendégéjszakák szállástípusonként (2001-).

A KSH adatai szerint hosszú távon megfigyelhető, hogy a fővárosban és a nyugati- vagy a középső országrészben élők gyakrabban engedhetik meg maguknak a többnapos belföldi utazást, mint a keleti 
országrész lakói. Ez a jelenség a társadalmi rétegek életvitelével, eltérő kulturális igényeivel és elsősorban anyagi lehetőségeiből adódó különbségekkel magyarázható. Magyarország legnépszerűbb városai közé tartozik Budapest után Hajdúszoboszló a belföldi vendégéjszakák alapján, a külföldiek által igénybe vett vendégéjszakák száma szerint a negyedik Budapest, Hévíz és Bük után [20].

A fenti adatok alapján megállapítható, hogy férőhelyek számának növekedését a vendégek és a vendég éjszakák számának növekedése meghaladja. Ennek oka egyrészt a szálláshelyek által nyújtott szolgáltatások minőségi javulása, másrészt a turisztikai attrakciók, rendezvények, hazai és nemzetközi konferenciák, sportrendezvények száma is folyamatosan nőtt. Ebben az Észak-alföldi régió is jelentős szerepet vállalt a megyeszékelyeken, a fürdővárosokban és a kisebb településeken a turisztikai célú rendezvényekkel. A felíveléshez az is hozzájárult, hogy a turizmus mára nem csak a tehetősek privilégiuma, hanem a középosztály egyre szélesebb csoportja számára is elérhető. Mindehhez a 2010es évek végétől jellemző trendeknek köszönhetően hozzájárult a fapados légitársaságok dinamikus térnyerése, az online marketing és online utazási irodák (a Szallas.hu, a Booking.com, az Expedia) elterjedése, valamint a közösségi szálláshelyek (az Airbnb és társai) megjelenése.

\section{Összefoglalás}

A turisztikai szektort érő különböző hatások közül a legfontosabb, ami hosszú távon jelentősen visszaveti a fejlődést, az a gazdasági válság. A 2008-2009-es válságot követően a statisztikai adatok igazolják, hogy a szektorban szinte minden területen visszaesés tapasztalható. 2011-től lassú fellendülés indult a gazdaságban, ha az emberek részesülnek a gazdasági prosperitásból, akkor utaznak, illetve a nagyobb nyaralások, hosszabb utazások mellett jellemzővé válik a több, rövidebb út vállalása [20]. Ezzel a turizmus a szabadidős funkcióján túl gazdaságélénkítő funkciója is érvényesül.

A támogatások hatékonyságának kimutatására a férőhelyek, a vendégek és az eltöltött vendégéjszakák számát vizsgáltuk. Bár számos projekt a szálláshelyek fejlesztését, bővítését célozta, növekedés csak szerény mértékben tapasztalható, az ország több régiójában a vizsgált időszakban inkább stagnált a férőhelyek száma. Ezzel szemben a vendégek és a vendégéjszakák számának folyamatos növekedése figyelhető meg, a legnagyobb növekedést a Közép-Magyarország régióban és Közép-Dunántúlon értek el. A statisztikai adatok alapján megállapítható, hogy 2008-ról 2017-re a szálláshelyeken a férőhelyek száma csak 16,1 \%-kal, a vendégek száma 55,3 \%-kal, az eltöltött vendégéjszakák száma 49 \%-kal növekedett. Ehhez nagyban hozzájárult egyrészt a turizmus globalizációja, az európai turisztikai célok megváltozása, átrendeződése. Előtérbe került az országok közötti választás szempontjai között a biztonság, másrészt a lassú gazdasági növekedés, a növekvő jövedelem kiáramlás, s mindezek a folyamatok a szálláshely-vendéglátás ágazat lassú fellendülését eredményezték az elmúlt években. Ezzel párhuzamosan a Regionális Operatív Program célrendszerében meghatározó helyett foglalt el a turisztikai ágazat fejlesztése. A program keretében az Észak-alföldi régióban 148 attrakciót, 34 szálláshelyfejlesztést és 8 turisztikai klasztert finanszíroztak. A fejlesztési forrásokért folyó versenyben az Észak-alföldi régió kedvező helyet ért el. A régióban Debrecent és Hajdúszoboszlót minősítették kiemelt gyógyhellyé, emellett a régi idegenforgalmában fontos szerepet játszik a Tisza és az egyedi természeti sajátosságokkal rendelkező, nemzetközileg elismert speciális puszta, a Hortobágy. 
A vizsgált időszak eredményeire az Európai Bizottság által elfogadott 2014-2020. évekre vonatkozó programok közvetlenül és közvetetten is hatással vannak. Magyarország 2020-ig 12000 milliárd forint fejlesztési forrást használhat fel az Európai Unió és a hazai költségvetés támogatásával. Magyarország által benyújtott és az Európai Bizottság által elfogadott operatív programok illeszkednek az EU2020 Stratégiához, amely az Európai Unió, s egyben Magyarország versenyképességének növekedését célozzák.

\section{Hivatkozások}

[1] A. Aubert - A. Horváth - B. M. Jónás - K. Szeidl (2017) A Dél-Dunántúl Régió turizmusa 19902015 között: leszakadás és differenciálódás. Közép-Európai Közlemények, 10 (3) pp. 73-90.

[2] É. Bácsné Bába (2014b) Festival in Tune with Students. In: M. Láczay - D. Fatula (szerk.): Social Aspects of Management: Personal Development, cultural changes, economic progress. Kraków: Krakow Society for Education; AFM Publishing House, 2014. pp. 75-88. ISBN:978-83-7571-283

[3] É. Bácsné Bába (2014a) Hallgatók, buli, Campus - Felsőoktatási hallgatók fesztivállátogatási szokásainak változása a Campus Fesztivál vizsgálata alapján. Turizmus Bulletin, 14 (2) pp. 3342.

[4] E. Kerényi - A. Müller - E. Könyves - I. Lázárné Fodor - A. Mosonyi (2010) Turisztikai márka és termékfejlesztés lehetôségei az egészségturizmusban az Észak-magyarországi és az Észak-alföldi régiókban. Acta Academiae Agriensis, 37 pp. 67.-73.

[5] E. Könyves - A. Müller (2007) Az Észak-alföldi régió turizmusfejlesztési stratégiája 2007-2013. In: A. Aubert (szerk.): Fejlesztés és képzés a turizmusban: II. Országos Turisztikai Konferencia tudományos közleményei. Konferencia helye, ideje: Pécs, Magyarország, 2006.10.122006.10.13. Pécs: Pécsi Tudományegyetem Természettudományi Kar Földrajzi Intézet, 2006. Paper 2007.

[6] E. Könyves - A. Müller - A. Mondok (2004) Az egészségturizmus lehetőségei Hajdúszoboszló példáján. In: VIII. Szolnoki Tudományos Közlemények (cd). 2004. Szolnoki Tudományos Napok. Városháza. Magyarország, Szolnok.

[7] E. Könyves - A. Müller - F. Szalay - R. Szabó (2005) Cserkeszôlő és Karcag egészségturizmusának összehasonlító elemzése. In: Szolnoki Tudományos Közlemények IX. (cd) A Magyar és a Világ tudomány napja. Városháza. Magyarország, Szolnok. pp. 2-9.

[8] Z. Lakner - A. Kiss - I. Merlet - J. Oláh - D. Máté - J. Grabara - J. Popp (2018) Building Coalitions for a Diversified and Sustainable Tourism: Two Case Studies from Hungary. Sustainability, 10 (4)

[9] G. Michalkó (2002) Az idegenforgalmi régiók gazdaságélénkítô szerepének problematikája. Földrajzi Értesítő. 51 (1-2) pp. 151-165.

[10] A. Müller - V. Kórik (2009) Az Észak-alföldi fürdôk szerepe a turizmusban és a rekreációban. Economica, 2 pp. 58-72.

[11] A. Müller - E. Könyves (2006) Az egészségturizmus lehetöségei az Észak-alföldi régióban. Acta Academiae Pedagogicae Agriensis - Az Eszterházy Károly Főiskola tudományos közleményei, 33 132-144.

[12] T. Pupos (2011) Turisztikai projektek menedzsmentje. Keszthely. 


\section{Internetes források:}

[13] Magyar Köztársaság Kormánya: Észak-alföldi operatív program 2007-2013 http://www.terport.hu/webfm send/312. letöltve: 2018.02.05.

[14] Gazdaságfejlesztési Operatív Program. http://www.terport.hu/webfm send/206. letöltve: $\underline{2018.02 .05 .}$

[15] Magyar Állami Számvevőszék (2015) a 2007-2013. évi EU költségvetési időszakban Magyarország részére juttatott közösségi támogatások összefoglaló bemutatásáról, értékeléséről. Tanulmány, Budapest. https://www.asz.hu/storage/files/files/Publikaciok/Elemzesek tanulmanyok/2015/2007 20 13 eu koltsegvetesi idoszakban magyarorszag reszere juttatott kozossegi tamogatasok ossz efoglalo bemutatasa ertekelese.pdf?ctid=855. letöltve: 2018.02 .05 .

[16] Az Észak-Alföldi Régió turizmusfejlesztési stratégiája (2007-2013). Magyar Turizmus Zrt. Készítette: Szolnoki Főiskola. 2006. https://www.google.com/search?q=\%C3\%A9szakalf\%C3\%B6ldi+r\%C3\%A9gi\%C3\%B3+turizmusfejleszt\%C3\%A9si+strat\%C3\%A9gi\%C3\%A1j a\&ie=utf-8\&oe=utf-8\&client=firefox-b. letöltve: 2018.02.05.

[17] EMIR, 2018. https://www.palyazat.gov.hu/egysges-monitoring-s-informcis-rendszer-emirszolgltatsainak-elrse. letöltve:2018. 02.25.

[18] Z. Polyánszky - Z. Ramasz Zoltán (2016) Regionális operatív programok 2007-2013-as forrásfelhasználásának területi elemzése. Századvég Gazdaságkutató Zrt. https://www.palyazat.gov.hu/download.php?objectId=74397. letöltve: 2018.02.06.

[19] KSH, 2018. http://www.ksh.hu/. letöltve: 2018.03.02.

[20] Jelentés a turizmus és vendéglátás 2016. évi teljesítményéről. $\mathrm{KSH}, 2017$. www.ksh.hu/docs/hun/xftp/idoszaki/jeltur/jeltur16.pdf. letöltve: 2018.03.25. 